\title{
Interleukin-31: The 'itchy' cytokine in inflammation and therapy
}

\author{
Angeliki Datsi ${ }^{1}$, Majid Alam², Fareed Ahmad ${ }^{2}$, Martin Steinhoff ${ }^{3}$, and Joerg Buddenkotte ${ }^{2}$ \\ ${ }^{1}$ Universittaetsklinikum Duesseldorf \\ ${ }^{2}$ Hamad Medical Corporation \\ ${ }^{3}$ Weill Cornell Medicine Qatar
}

November 27, 2020

\begin{abstract}
Interleukin-31 has been implicated in the pathophysiology of multiple atopic disorders such as atopic dermatitis (AD), rhinitis and airway hyperreactivity. In AD, IL-31 has been identified as one of the main 'drivers' of its cardinal symptom pruritus. Here, we aim to summarize the mechanisms by which IL-31 modulates inflammatory and allergic diseases. TH2 cells play a central role in $\mathrm{AD}$ and release high levels of TH2-produced cytokines including IL-31, thereby mediating inflammatory responses, initiating immunoregulatory circuits, and stimulating itch and neuronal outgrowth through activation of the heterodimer receptor IL-31 receptor alpha (IL31RA)/Oncostatin M receptor $\beta$. IL31RA expression is found on human and murine dorsal root ganglia neurons, epithelial cells including keratinocytes as well as various innate immune cells. IL-31 is a critical cytokine involved in neuro-immune communication, which opens new avenues for cytokine modulation in neuroinflammatory diseases including $\mathrm{AD} /$ pruritus, as validated by recent clinical trials using an anti-IL-31 antibody. Accordingly, inhibition of IL-31 downstream signaling may be a beneficial approach for various inflammatory diseases including prurigo nodularis. For example, whether downstream JAK inhibitors directly block IL-31-mediated-signaling needs to be clarified. Targeting the IL-31/IL31RA/OSMR $\beta$ axis appears to be a promising approach for inflammatory, neuroinflammatory and pruritic disorders in the future.
\end{abstract}

Angeliki Datsi, PhD (ORCID ID: 0000-0001-5022-8087)

Majid Alam, PhD (ORCID ID: 0000-0002-5783-6605)

Fareed Ahmad, PhD (ORCID ID: 0000-0003-2827-8744)

Martin Steinhoff, MD, PhD (ORCID ID: 0000-0002-7090-2187)

Joerg Buddenkotte, MD, PhD (ORCID ID: 0000-0002-2394-3269)

Article type: Review

Interleukin-31: The 'itchy' cytokine in inflammation and therapy

Running title: Interleukin-31 in inflammation and allergy

Angeliki Datsi ${ }^{1}$, Majid Alam ${ }^{2,3}$, Fareed Ahmad $^{2,3}$, Martin Steinhoff ${ }^{2-7^{*}}$, and Joerg Buddenkotte ${ }^{2,3}, *$

\section{Affiliations}

${ }^{1}$ Institute for Transplantational Diagnostics and Cell Therapeutics, University Hospital Düsseldorf, Düsseldorf, Germany; ${ }^{2}$ Department of Dermatology and Venereology, Hamad Medical Corporation, Doha, Qatar; ${ }^{3}$ Translational Research Institute, Academic Health System, Hamad Medical Corporation, Doha, Qatar; ${ }^{4}$ Dermatology Institute, Academic Health System, Hamad Medical Corporation, Doha, Qatar; ${ }^{5}$ Department 
of Dermatology, Weill Cornell Medicine-Qatar, Doha, Qatar; ${ }^{6}$ Qatar University, College of Medicine, Doha, Qatar; ${ }^{7}$ Department of Dermatology, Weill Cornell Medicine, New York, USA

Short running title: 38 characters $(<50$ characters)

Review text word count: 4878/4500 (not including abstract, figure legends, references)

Abstract word count: 199/250

Figures and tables: 1 table/3 figures/4 total (10 max)

Keywords: $5 / 5$

References: $97 / 200$

* Corresponding authors

Joerg Buddenkotte, MD, PhD \& Martin Steinhoff, MD, PhD

Department of Dermatology and Venereology, Hamad Medical Corporation and Translational Research Institute, Academic Health System, Hamad Medical Corporation, Doha, Qatar

Email: JBuddenkotte@hamad.qa and MSteinhoff@hamad.qa

\section{Funding}

Supported by the National Priorities Research Program (NPRP11S-0117-180326) of the Qatar National Research Fund, Member of Qatar Foundation, and the Internal Research Grand Competition (IRGC-04-SI17-151) of the MRC Fund, Hamad Medical Corporation, Qatar (to M.S. and J.B.).

\section{Acknowledgements}

We thank Javeria Haroon for assisting in the preparation of the figures using BioRender.com.

\section{Author contribution}

A.D., M.S. and J.B. conceptualized and wrote the review. M.A. and F.A. critically revised the manuscript.

Abbreviations: AAM, alternatively activated macrophage; AD, atopic dermatitis; AHR, airway hyperreactivity; AE, adverse event; AKT, protein Kinase B; APC, antigen presenting cell; CCL, chemokine (C-C motif) ligand; CD, cluster of differentiation or Crohn's disease; CDC2, cell division cycle protein 2 homolog; CDK6, cell division protein kinase 6; CLA, cutaneous lymphocyte antigen; CNTF, ciliary inhibitory factor; CT-1, cardiotropin-1; CCL, chemokine (C-C motif) ligand; CXCL, chemokine (C-X-C motif) ligand; DC, dendritic cell; DLQI, Dermatology Life Quality Index; DRG, dorsal root ganglion; EASI, Eczema Area Severity Index; EGF, endothelial growth factor; ERK, extracellular signal-regulated kinase; GRO- $\alpha$, growth-related oncogene- $\alpha$ ? FDA, Food and Drug Administration; gp, glycoprotein; GIT, gastrointestinal tract; HLA-DR, histocompatibility antigen-DR; HDM, house dust mites; IBD, inflammatory bowel disease; IGA, Investigator's Global Assessment; IgG, immunoglobulin G; IL, interleukin; IL31RA, IL-31 receptor-??? JAK, janus kinase; JNK, c-Jun N-terminal kinase; LIF, leukemia inhibitory factor; LOCF, Last Observation Carried Forward; MAPK, Mitogen-activated protein kinase; MI, Multiple Imputation; mTOR, mammalian target of rapamycin; NA, not available; NFAT1, nuclear factor of activated T-cells; NGF, nerve growth factor; NP, nasal polyps; NPN, neuropoietin; NRS, Numeric Rating Scale; OSM, oncostatin M; OSMR $\beta$ ??? oncostatin $\mathrm{M}$ receptor beta; $\mathrm{PbO}$, placebo; $\mathrm{PCR}$, polymerase chain reaction; ppNRS, peak pruritus Numerical Rating Scale; PI3K, phosphoinositide 3-kinase; PRR, pattern recognition receptor; Pt, part; p38, p38 mitogenactivated protein kinase; SA, Staphylococcus aureus; SEB, staphylococcal enterotoxins; SMAD2/3, mothers against decapentaplegic homolog 2/3; SOCS, suppressor of cytokine signaling; STAT, signal transducer and activator of transcription; TARC, thymus- and activation-regulated chemokine; TGF- $\beta$ ?? transforming growth factor beta?? $\mathrm{T}_{\mathrm{H}}$, T helper cell; TLR, toll like receptor; TNF $\alpha$ ??tumor necrosis factor alpha; TRP, transient receptor potential; TRPA1, TRP ankyrin receptor 1; TRPV1, TRP vanilloid receptor 1; TSLP, thymic stromal lymphopoietin; T1/ST2 receptor, Interleukin 1 receptor-like 1 ; Tc1, type $1 \mathrm{CD} 8^{+} \mathrm{T}$ cells; 
Tc2, type $2 \mathrm{CD}^{+} \mathrm{T}$ cells; UC, ulcerative colitis; VAS, Visual Analog Scale; VEGF, vascular endothelial growth factor; $\Delta$, change.

\begin{abstract}
Interleukin-31 has been implicated in the pathophysiology of multiple atopic disorders such as atopic dermatitis (AD), rhinitis and airway hyperreactivity. In AD, IL-31 has been identified as one of the main 'drivers' of its cardinal symptom pruritus. Here, we aim to summarize the mechanisms by which IL-31 modulates inflammatory and allergic diseases. $\mathrm{T}_{\mathrm{H}} 2$ cells play a central role in $\mathrm{AD}$ and release high levels of $\mathrm{T}_{\mathrm{H}}$ 2-produced cytokines including IL-31, thereby mediating inflammatory responses, initiating immunoregulatory circuits, and stimulating itch and neuronal outgrowth through activation of the heterodimer receptor IL-31 receptor alpha (IL31RA)/Oncostatin M receptor $\beta$. IL31RA expression is found on human and murine dorsal root ganglia neurons, epithelial cells including keratinocytes as well as various innate immune cells. IL-31 is a critical cytokine involved in neuro-immune communication, which opens new avenues for cytokine modulation in neuroinflammatory diseases including $\mathrm{AD} /$ pruritus, as validated by recent clinical trials using an anti-IL-31 antibody. Accordingly, inhibition of IL-31 downstream signaling may be a beneficial approach for various inflammatory diseases including prurigo nodularis. For example, whether downstream JAK inhibitors directly block IL-31-mediated-signaling needs to be clarified. Targeting the IL-31/IL31RA/OSMR $\beta$ axis appears to be a promising approach for inflammatory, neuroinflammatory and pruritic disorders in the future.
\end{abstract}

Key words: Interleukin-31, Interleukin-31 receptor A, Oncostatin M receptor, atopic dermatitis, neuroinflammation.

\title{
Introduction
}

\section{IL-31 structure and function}

The first major role of IL-31 was described in an induced mouse model of atopic dermatitis (AD), where it was reported to cause cutaneous inflammation along with pruritus when IL-31 was genetically overexpressed. ${ }^{1}$ Ever since this observation, IL-31 and its respective receptor heterodimer IL-31 receptor-A (IL31RA)/Oncostatin M receptor $\beta$ (OSMR $\beta$ ) have been studied for their role in tissue homeostasis, inflammation, immune defence, neuroimmune circuits and pruritus.

IL-31 belongs to the family of IL-6-derived cytokines. Interleukin-6 family cytokines are commonly clustered based on their pro-inflammatory character and a shared signaling pathway engaging in gp130 receptor subunit activation. The IL-6 cytokine family is often referred to as the gp130/IL-6 family of cytokines. Family members are IL-6, IL-11, IL-21, IL-27, neuropoietin (NPN), ciliary inhibitory factor (CNTF), cardiotropin-1 (CT-1), leukemia inhibitory factor (LIF), oncostatin M (OSM) and IL-31. Apart from IL-31, IL-6 family cytokines signal through a heterodimeric receptor composed of two subunits of which one typically is gp $130{ }^{2}$ IL-31 does not engage with gp130 itself, but rather interacts with a heterodimer complex that is composed of the gp130-like subunit IL31RA and OSMR $\beta .{ }^{1}$ This receptor heterodimer is activated with similar affinities by oncostatin M (OSM) and IL-31. The OSMR $\beta$ subunit is widely expressed throughout the various cell types of the mammalian body, while IL31RA subunit expression is predominantly observed in epithelial and neuronal cell types. In humans, IL31RA forms either a long or a short isoform, with the short isoform resuming a nonsignaling inhibitory function. In rodents, only the long isoform has been detected. ${ }^{3}$ Engagement of OSM or IL-31 with the IL31RA/OSMR $\beta$ heterodimer initiates activation of canonical JAK/STAT, AKT/PI3K and MAPK-JNK/p38 pathways (Figure 1). Of note, at least MAPK activity is not inducible by signaling through the IL31RA alone but needs both receptor subunits to cooperate. ${ }^{4}$ Activation of IL-31 signaling pathways leads to the induction of various cellular processes including cell survival, proliferation and differentiation.

The physiological function of IL-31 is still not fully understood. Recently, a major role for IL-31 in humans has been described in various inflammatory disorders, including $\mathrm{AD}$, inflammatory bowel disease (IBD), nasal polyposis (NP) and airway hyperreactivity (AHR).

IL-31 has been identified as a secretory product of $\mathrm{T}_{\mathrm{H}} 2$ cells and immature dendritic cells (iDC), ${ }^{5}$ and ac- 
tivates IL31RA/OSMR $\beta$ receptor expressing dorsal root ganglia (DRG) neurons and keratinocytes, among others, ${ }^{3,5-7}$ linking immune cells to epithelium and the neuronal network in the skin, and probably also gut and airways. ${ }^{6}$ Intradermal application of IL-31 indeed leads to sensations of itch, underlying the capacity of IL-31 to activate target neurons. ${ }^{8}$ Here, we summarize our current understanding about the pathophysiological role of the IL-31/IL31RA/OSMR $\beta$ axis in skin and mucosa, with an emphasis on neuro-immune communication and its translational importance for the treatment of inflammatory and neuroimmune diseases of skin, gut and airways in the future.

\section{IL-31 and the immune system}

The source of IL-31 and the factors modulating IL-31 expression are still poorly understood. Several studies point to a preferential expression of IL-31 in mice and humans by CD3 ${ }^{+} \mathrm{CD} 4^{+}$type 2 T-helper cells $\left(\mathrm{T}_{\mathrm{H}} 2\right){ }^{1,5,9,10}$ A recent large-scale tissue bank screening approach confirmed almost exclusive expression of IL-31 by $\mathrm{CD}^{+}{ }^{+} \mathrm{CD} 4^{+}$immune cells. ${ }^{11}$ Stott et al . propose that in humans IL-31 expression in CD3 ${ }^{+}$ $\mathrm{CD} 4^{+} \mathrm{T}_{\mathrm{H}} 2$ cells is under primary control of IL-4 whereas IL-33 stimulation seems to boost IL-31 secretion human $\mathrm{T}_{\mathrm{H}} 2$ cells via a STAT6-dependent regulation of T1/ST2 receptor. ${ }^{9,11,12}$ In contrast, TGF- $\beta$ has a rather damping effect on IL-31 secretion via phosphorylation of SMAD2/3 molecules. This effect might explain why fully differentiated $\mathrm{T}_{\mathrm{H}} 9$ cells express only moderate IL-31 levels since differentiation of $\mathrm{T}_{\mathrm{H}} 9$ is initiated by co-stimulation with IL- 4 and TGF- $\beta$. While the IL- 4 signal initiates IL-31 expression, the simultaneous TGF- $\beta$ signal dampens IL-31 expression counter-regulating the IL- 4 effect. $\mathrm{T}_{\mathrm{H}} 2$ cells, in comparison, are not relying on TGF- $\beta$ as they differentiate from naïve T cells dependent on IL-4 signaling from the microenvironment alone and maintain their phenotype by autocrine IL- 4 signaling which in parallel supports IL-31 expression. ${ }^{9}$ The transcription of theIl31 gene in $\mathrm{T}_{\mathrm{H}} 2$ and (probably IL-4 producing) mast cells is under control of calcium-dependent NFAT1 and NFAT2 and a 'usual suspect' of cytokine expression regulators, the protein family of suppressor of cytokine signaling (SOCS), was found to have a pivotal role in suppression of 'uncontrolled' IL-31 expression (Figure 1). ${ }^{13,14}$ However, it remains unclear how secretion of IL-31 is restricted to IL-4-expressing cells ( $\mathrm{T}_{\mathrm{H}} 2$ cells in particular) and if IL- $31^{+} \mathrm{T}_{\mathrm{H}} 2$ cells could mark a distinct subpopulation within $\mathrm{T}_{\mathrm{H}} 2$ cells. Notably, our knowledge about the communication between IL-31 and IL-13 or TSLP is very poor.

\section{IL-31 in neuro-immune communication}

Multiple mediators including cytokines can induce pruritus (itch) which can develop into being intractable by nature, as seen in skin diseases or systemic disorders such as allergies, metabolic diseases or cancer. ${ }^{15-17}$ Peripheral nerve endings in the epidermis and dermis become activated by various endogenous or exogenous trigger factors during inflammation, allergies or systemic diseases. ${ }^{18,19}$ After activation of cytokine receptors on sensory nerve endings, like IL31RA, the nerves transmit the itch or pain signal to the central nervous system via the spinal cord and contralateral tractus spinothalamicus. ${ }^{20,21}$ Through an axon-reflex mechanism, ${ }^{22}$ neighbouring nerve branches become activated and release neuropeptides into the skin thereby inducing neurogenic inflammation, which can be also induced by IL-31. ${ }^{23,24}$ For example, IL-31 induced b-type natriuretic peptide (BNP) release from murine DRG neurons and skin cells mediated neuroinflammation by stimulating cytokine, chemokine and endothelin-1 (ET-1) release from keratinocytes. ${ }^{23,24}$ Multiple pruritogens, their cognate receptors, channels and interaction networks have been identified. ${ }^{15,25-27}$ The capsaicin receptor TRP vanilloid receptor 1 (TRPV1) and mustard oil activated TRP ankyrin receptor 1 (TRPA1) are expressed on DRG neurons and are essential for the correct pruritic signal transmission of diverse pruritogens including IL-31. ${ }^{6,28-31}$ Together, these studies point at an essential role of IL-31 for the neuroimmune communication between $\mathrm{T}_{\mathrm{H}} 2$ cells, sensory nerves and keratinocytes, thereby initiating inflammation, epithelial dysregulation and pruritus, all characteristics of atopic dermatitis pathophysiology.

Cytokines have been found to act as pruritic sensitizers or activators, respectively, dependent on the concentration. ${ }^{32,33}$ In genetically modified mice, overexpression of only a single cytokine (demonstrated for IL-4, IL-13, IL-18, IL-31 or TSLP) is sufficient to cause pruritic AD-like skin lesions. ${ }^{25}$ In humans, our current knowledge points at IL-4 and IL-13 being the major molecular 'drivers' of AD. ${ }^{32,34}$ However, a transgenic mouse model demonstrated that overexpression of IL-31 is enough to initiate a severe AD-like 
phenotype with eczema and itch. ${ }^{1}$ In addition, implantation of GABAergic interneurons into the spinal cord of IL-31-overexpressing mice induced healing of skin lesions and alleviated pruritus. ${ }^{35}$ In AD patients, elevated expression levels of IL-31 and IL31RA were found in a significant amount of patients, but not all. While some patients showed high levels for IL-31 mRNA and IL31RA mRNA, others showed low levels for both, some low levels for either IL-31 or IL31RA. ${ }^{6}$ This result supports the hypothesis about AD being a clinically and molecular heterogenic disease in which patients differ with respect to their expression levels for IL-4, -13 and -31 . This, of course, needs to be verified/falsified in the future.

Furthermore, IL31RA expression can be found in human dorsal root ganglia (sensory nerves), skin-infiltrating mononuclear cells and CD11b+ cells, establishing an important role of IL-31 in human AD as well. Considering that $\mathrm{T}_{\mathrm{H}} 2$ cells represent the main source of IL-31, the IL-31 axis could serve as a strong neuro-immune link between IL-31-expressing T cells and IL31RA-expressing sensory neurons. ${ }^{5,36}$ The receptor is predominantly expressed by small-to-medium size human DRG neurons $(<30 \mu \mathrm{m})$ co-expressing TRPV1 while large-diameter DRG neurons $(<50 \mu \mathrm{m})$ are mainly IL31RA-negative. ${ }^{36}$ In mice, both TRPV1 and TRPA1 ion channels are functionally linked to IL31RA since genetically (TRPV1, TRPA1 KO mice) or chemical blocking of TRPV1 can abrogate IL-31-mediated itch. ${ }^{6}$

A study conducting transcriptomics-based analysis in IL-31-activated DRG neurons revealed that IL-31 is further involved in neuronal proliferation, survival and metabolism. ${ }^{37}$ Pump-equipped mice receiving a continuous IL-31 stimulus over weeks develop a denser cutaneous neural network than vehicle-treated control mice. The IL-31-mediated increase in cutaneous nerve fibre density is achieved by a STAT3-dependent increase in branching, extension and quantity of small-diameter sensory neurons along with the induction of neuronal survival via PI3K/AKT pathway activation. ${ }^{37}$ These findings may partly explain the increased epidermal sensory nerve fibre density in AD patients. ${ }^{38-42}$ which probably accounts for the higher 'skin sensitivity' in AD patients to minimal stimuli. This is in line with the assumption that neural changes occur in direct response to on-going inflammatory signals in AD. However, a recent study conducted in a mouse model of AD utilizing continuousin vivo imaging of peripheral sensory nerves and blood vessels implicates that neural changes might preceed immune cell infiltration, vascularization and vascular permeability. ${ }^{40}$ The author suggests that 'allergic stimulation in a chronic eczema model requires neural recruitment and activation early in the process for the initiation and maintenance of the inflammatory cascade'. ${ }^{40}$ With early neuronal imprinting established, subsequent recruitment of IL- $31^{+} \mathrm{T}$ cells to neuronal IL31RA ${ }^{+}$structures $^{-}$ and immuno-neuronal communication could then feed into the severity of itch, inflammation, and changes of the epidermal nerve fiber density characteristic for $\mathrm{AD}$.

\section{IL-31 and its role in mucosal diseases}

Multiple studies have established a role for members of the IL-6 family in the regulation of epithelial cell function in lung, skin and gastrointestinal tract (GIT). ${ }^{43-45}$ Mucosal epithelial cells express OSMR $\beta$ that can be activated by IL-31 and OSM. ${ }^{5}$ While the downstream effect of OSM interaction with its cognate receptor is well-described, ${ }^{46,47}$ evidence is emerging for a significant role of IL-31 mediating inflammatory processes at mucosal sites. Mucosal sites are protected by an epithelial barrier, which senses incoming pathogens or allergens, and can respond to these by release of "alarmins" including IL-33, a cytokine of the IL-1 family which signals through its cognate T1/ST2 receptor connecting epithelial sites with the immune system by activating eosinophils, mast cells and $\mathrm{T}_{\mathrm{H}} 2$ lymphocytes. ${ }^{48,49}$ In particular IL-33-driven activation of $\mathrm{T}_{\mathrm{H}} 2$ lymphocytes results in effective secretion of IL-31 from $\mathrm{T}$ cells, which can subsequently activate IL31RA/OSMR $\beta^{+}$epithelial cells, neurons and tissue-residing immune cells.

\section{The IL-31 axis in the skin}

The role of the IL-31/IL31RA axis in pruritus and pruritic disorders such as AD is firmly accepted, although precise aspects about the pathophysiological role of IL-31 signaling remain to be elucidated. In humans, IL-31 acts as a pruritogen but evokes a rather late itch response when applied intradermally. ${ }^{50}$ In $\mathrm{AD}$ patients, serum IL-31 and IL-33 levels are found to be increased when compared to healthy volunteers, nurturing the hypothesis that IL-33 might stimulate the secretion of IL-31 from $\mathrm{T}_{\mathrm{H}} 2$ cells or epithelial cells 
in vivo. ${ }^{51}$ In the skin, IL-31 enforces tissue alterations that are typically seen in AD patients (Figure 2). A recent study associated IL-31 with epidermal thickening as well as impaired skin barrier function and impaired mechanical integrity due to reduced junction plakoglobin ( Jup ) gene expression. ${ }^{52}$ In organotypic skin models, IL-31 signaling induced differentiation defects depicted by the deficit in filaggrin expression and a reduction of the lipid envelope. ${ }^{53}$ Gene expression analysis confirmed a direct IL-31 dependent regulation of genes involved in skin barrier and identified the IL-1 cytokine network as a downstream effector of IL-31 signaling. ${ }^{54}$ Accordingly, anakinra-mediated IL1R blockage was effective to abrogate IL-31-mediated loss of skin differentiation. However, complete inhibition of IL-31 signaling might not be a desirable therapeutic outcome, since low doses of IL-31 are needed for the release of antibacterial peptides from keratinocytes. ${ }^{54}$

In vitro data from mouse keratinocytes suggest involvement of IL-31 in immune-cell recruitment, an important process during AD development. IL-31 initiates the release of various immune cell-attracting chemokines such as CCL4, CCL17, CCL22 and CCL25. ${ }^{1}$ CCL17 and CCL22, for instance, recruit cutaneous lymphocyte antigen $\left(\mathrm{CLA}^{+}\right)$-expressing $\mathrm{T}$ cells to the epidermis. This immune cell subset is of major interest in $\mathrm{AD}$ since $\mathrm{CLA}^{+} \mathrm{T}$ cells are abundant allergen-reactive $\mathrm{T}$ cells in the circulation and lesional skin of $\mathrm{AD}$-affected patients. ${ }^{55}$ Whether IL-4- and IL-13-producing CLA ${ }^{+} \mathrm{CD}^{+} \mathrm{T}$ cells or specific subtypes express IL-31 is not known but anticipated. However, the epidermis of AD-derived skin expresses elevated levels of IL31RA and forms a 'sensitized' target for IL-31. ${ }^{10}$ 'AD-conditioned' keratinocytes could perpetuate the recruitment of $\mathrm{CLA}^{+}$, probably IL- $31^{+}-\mathrm{T}_{\mathrm{H}} 2$ cells to the skin via release of chemokines, which in turn further activate keratinocytes via IL-31, thereby completing a positive feedback loop between the skin and immune system communication (Figure 1). That circuit would result in the progression of inflammation, pruritus and impaired skin barrier, thus progression of $\mathrm{AD}$. The critical factor(s) that modulate(s) epidermal IL31RA expression levels in $\mathrm{AD}$ in vivo is not known yet. However, pro-inflammatory signals such as IFN $\gamma$ or neuropeptides like BNP are candidates, highlighting the importance of functional IL-31 in pro-inflammatory environments. ${ }^{23,24,56}$

Recent observations emphasize the importance of skin-resident memory $\mathrm{T}$ cells $\left(\mathrm{CD} 3^{+} \mathrm{CD} 45 \mathrm{RO}^{+} \mathrm{CLA}^{+}\right)$for $\mathrm{AD}$ onset. ${ }^{10,57-59}$ Most of the skin-resident memory $\mathrm{T}$ cells are antigen-experienced and expresses the surface histocompatibility antigen-DR (HLA-DR). Challenge of this $\mathrm{T}$ cell subset with AD-associated bacterial superantigens such as staphylococcal enterotoxins B (SEB) or house dust mites (HDM)-derived antigens enhances the effector phenotype of the cutaneous $\mathrm{T}_{\mathrm{H}} 2$ pool. ${ }^{60,61}$ Such priming and expansion of skin-resident memory $\mathrm{T}$ cells by antigens originating from skin-colonizing Staphylococcal aureus (SA) and HDM is a common observation in AD patients. Recently, elevated frequencies of HDM-reactive IL- $31^{+} \mathrm{T}$ cells were observed in the periphery of chronic $\mathrm{AD}$ patients associated with decreased $\mathrm{T}_{\mathrm{H}} 1 / \mathrm{T}_{\mathrm{H}} 2$ and $\mathrm{Tc} 1 / \mathrm{Tc} 2$ ratios. ${ }^{62}$ This finding indicates that allergen-specific $\mathrm{T}$ cells are subject to pre-existing $\mathrm{T}_{\mathrm{H}} 2$ - $\mathrm{Tc} 2$ and that IL-31 may be involved in $\mathrm{T}_{\mathrm{H}} 31-\mathrm{Tc} 31$ programming. ${ }^{62}$ The capacity of SA-specific T cells to produce and secrete IL-31 has not been tested yet. However, SEB is known to activate multiple $\mathrm{T}$ cell subsets, to act nonspecifically, and thereby might be ineffective to expand an IL-31 ${ }^{+} \mathrm{T}$ cell subset. ${ }^{56,60} \mathrm{~A}$ more general stimulation of toll-like receptor (TLR)-2 by bacterial cell wall components or 'atopic' cytokines increased IL31RA- and OSM-expression levels as well as CCL2 release in human keratinocytes, linking IL-31 to skin colonization and innate immunity. ${ }^{56}$ Priming of $\mathrm{T}$ cells, however, is a complex process, which relies on an intricate interplay between the innate and adaptive immune system. Patrolling phagocytes of the adaptive immune system recognize via TLRs or pattern-recognition receptors (PRRs) invading pathogens or allergens and present them to cells of the adaptive immune system, such as $\mathrm{CD} 4^{+} \mathrm{T}$ helper cells. The most effective antigen-presenting cells (APCs) are tissue resident dendritic cells (DCs), which capture the antigen and depending on the subsequent activation of the respective TLR - activate either effector or regulatory T cells. Like keratinocytes, exposure of primary human $\mathrm{CD} 1 \mathrm{c}^{+}$and monocyte-derived dendritic cells to IL-31 results in STAT-1 activation and subsequent IL31RA increase. ${ }^{63} \mathrm{IL}$-31-stimulated dendritic cells secrete an extensive number of pro-inflammatory cytokines such as tumor necrosis factor alpha (TNF $\alpha)$, IL-6, IL-8 and chemokines such as CCL2, CCL5 and CCL22, leading to amplified tissue inflammation. ${ }^{63}$ DC-derived cytokines induce a massive influx of immune cells including $\mathrm{T}_{\mathrm{H}} 2$ cells and eosinophils. A recent study reports that eosinophils express IL31RA, ${ }^{64}$ and that IL-31 functions as a survival signal lowering the rate of apoptosis in these 
cells. ${ }^{65}$ Thus, IL-31 signaling may offer a survival advantage to AD-associated eosinophils reinforcing the inflammatory cascade. Uncontrolled clonal expansion of effector $\mathrm{T}$ cells leads to the recruitment of additional eosinophils and $\mathrm{CD} 68^{+}$macrophages. ${ }^{10}$ Finally, activated DCs participate in the activation of CD4 ${ }^{+} \mathrm{T}$ cells, including $\mathrm{T}_{\mathrm{H}} 2$ cells, by presenting SEB- or HDM-antigen to tissue-resident or infiltrated naïve T-cells.

\section{Translational importance of IL-31 and clinical trials}

The $\mathrm{T}_{\mathrm{H}} 2$ cytokines IL- 4 and IL-13 have recently been identified as central mediators of AD, leading to the development of antibodies targeting IL-4 or IL13, or both, for AD treatment. ${ }^{34,66}$ In particular, the success of dupilumab, a fully human IgG4 $x$ monoclonal antibody binding to the $\alpha$ - subunit of the interleukin- 4 receptor $\left(\operatorname{IL} 4 \mathrm{R} \alpha\right.$ ), validated an essential role of the $\mathrm{T}_{\mathrm{H}} 2$ (type-2) inflammatory axis in AD. Dupilumab treatment achieved a rapid and robust improvement of skin lesions and pruritus and has been designated as a breakthrough therapy for AD by the US Food and Drug Administration (FDA). ${ }^{67}$

Considering the multifaceted role of IL-31 in $\mathrm{T}_{\mathrm{H}} 2$-driven $\mathrm{AD}$, efforts have been intensified to develop agents that efficiently block also the IL-31/IL31RA axis. Early IL-31/IL31RA inhibition approaches in NC/Ngainbred mice resulted in the first observation of reduced scratching. ${ }^{68}$ Several follow up studies demonstrated that blocking of IL31RA by a neutralizing antibody effectively prevented itch in AD mouse models and AD patients. ${ }^{69-74}$ IL-31-dependent pruritic activity has been described in mice, canines, primates and humans despite the low inter-species homology of the cytokine. ${ }^{75-77}$

Michels et al., demonstrated that subcutaneous administration of lokivetmab, a caninized anti-canine monoclonal anti-IL-31 antibody, alleviates itch symptoms in dogs with AD. ${ }^{77,78}$ The decrease of itch was stable for over a month and associated with decreased IL-31 serum levels. ${ }^{78}$ Similar results have been obtained in cynomolgus monkeys, where an AD-like phenotype was caused by administration of human and cynomolgus IL-31. ${ }^{75,79}$ Moreover, blockage of IL-31 signaling using an anti-IL31RA antibody resulted in significant itch reduction. 27714851

In humans, the first data of a clinical phase I/Ib trial assessing the efficacy of a humanized anti-IL31RA monoclonal antibody (CIM331, nemolizumab) revealed a marked dose-dependent reduction of pruritus after a single subcutaneous dose (Table 1 ) $\cdot{ }^{72}$ Nemolizumab inhibited IL-31-mediated cell signaling efficaciously and safely, reduced pruritus to about $50 \%$ at week 4, improved sleep efficiency and decreased use of topical hydrocortisone..$^{72}$ A follow-up trial concluded the safe use of nemolizumab with no significant adverse event in combination with corticosteroid therapy. ${ }^{73}$ In this phase-II clinical trial, nemolizumab $(0.1,0.5,2$ $\mathrm{mg} / \mathrm{kg}$ ) reduced itch by $43.7 \%, 59.8 \%, 63.1 \%$, respectively, compared to $20.9 \%$ itch reduction with placebo $(\mathrm{P}<0.01)$. Changes in the Eczema Area Severity Index (EASI) score were $-23.0 \%,-42.3 \%$, and $-40.9 \%$ in the nemolizumab groups versus $-26.6 \%$ in the placebo group. The affected body surface area (BSA) was reduced by $7.5 \%, 20.0 \%$, and $19.4 \%$ in the nemolizumab groups vs. $15.7 \%$ in the placebo group. Thus, nemolizumab every 4 weeks significantly improved pruritus in moderate-to-severe $\mathrm{AD}$, was safe and well tolerated. In contrast, the secondary endpoints (EASI, BSA) were not significantly different in treatment and placebo group at 12 weeks with chosen dosages. ${ }^{80}$ A phase-IIb clinical trial investigated the effects of nemolizumab $(10,30$, and $90 \mathrm{mg}$ ) administered every 4 weeks over 24 weeks in adults with uncontrolled moderate-to-severe AD associated with severe pruritus. ${ }^{80}$ Concomitant topical corticosteroid treatment was allowed. Here, $30 \mathrm{mg}$ nemolizumab was the most efficacious, markedly improving EASI, Investigator's Global Assessment (IGA), and Peak Pruritus Numerical Rating Scale (ppNRS) vs. placebo group already at week 8, but not week 24, with an overall acceptable safety profile. A phase-III follow-up extension study investigated Japanese adult patients with moderate-to-severe $\mathrm{AD}$ and pruritus treated with nemolizumab (60 $\mathrm{mg}$, every 4 weeks) versus placebo over 16 weeks. $^{74}$ Here, nemolizumab reduced the median VAS score by $42.8 \%$ vs. placebo $(21.4 \%$, $\mathrm{P}<0.001$ ). Mean EASI score, Dermatology Life Quality Index (DLQI) score also improved in nemolizumab group compared to the placebo group. Injection site reaction was the most frequent adverse event. Finally, a recent phase-II, long-term extension study was published in moderate-to-severe atopic dermatitis. ${ }^{71} \mathrm{Im}$ provement of itch was observed at week 64 with $0.5-\mathrm{mg} / \mathrm{kg}$ nemolizumab. No long-term safety concerns were identified. Since AD is a clinically heterogeneous disease it will be important to better understand the subtypes of $\mathrm{AD}$ which will profit the most from the current and future therapies targeting IL-4, -13 and -31 . 


\section{IL-31 in Mucosal Airway and Intestine}

Recently, IL-31 signaling has been detected in mucosal sites of the human lung, nasal sinus and intestine (Figure 3). ${ }^{81-83}$ Lung epithelial cells express IL31RA, OSMR $\beta$ and gp130. Although both, OSM and IL-31, engage with equal affinities to IL31RA/OSMR $\beta$ of lung epithelium and activate common signal transduction pathways, each agonist can activate distinct downstream signaling cascades. ${ }^{81}$ For instance, OSM activation leads to balanced phosphorylation of STAT3, ERK and STAT5, whereas IL-31 increases STAT3 phosphorylation, while attenuating STAT5 responses and leaving pERK levels unaffected. ${ }^{81}$ Neither OSM nor IL-31 initiate the expression of any of the other "classical" IL-6 targets such as STAT1. ${ }^{81}$ STAT3 signaling has been linked to both proinflammatory and anti-inflammatory responses and is involved in regenerative processes, such as proliferation and inhibition of apoptosis. ${ }^{84,85}$ As to whether IL-31 is implicated in these functional roles within intestinal epithelium via STAT3 activation has yet to be determined.

In the epithelial-like human lung adenocarcinoma cell line (A549), IL-31 induces morphological changes characterized by formation of podosomal extensions and a reduction in cell-cell interactions. ${ }^{81}$ Furthermore, IL-31 activation induces cell-cycle arrest and an impaired regulation and expression of cell cycle proteins such as cyclin B1, CDK6 and CDK1 (CDC2), and suppressing proliferation. This indicates a profound role of IL31 in tissue homeostasis. ${ }^{81}$ Of note, the responses of lung epithelial cells to IL-31 activation can vary due to the inducible expression of IL31RA and differences in receptor abundance between donors. For example, the expression of IL31RA is transiently downregulated after engagement of its ligand by downstream signaling effects. $^{81}$

In $\mathrm{T}_{\mathrm{H}}$ 2-dominated asthmatic or non-asthmatic airway inflammation changes in IL31RA abundance could be essential, since IL-31 was found to support the progression of the asthmatic phenotype leading to the notion by some that IL-31 might serve as a marker of allergic asthma. ${ }^{51,86,87}$ Contrary to findings in the skin, this study suggests that the culprit IL-31 would not be exclusively expressed by $\mathrm{T}$ cells but rather stems from unidentified cells in the lung that respond to IL-4. Interestingly, IL-33 is secreted continuously by lung epithelial cells during asthmatic inflammatory reactions as an alarm signal against invading pathogens and allergens ${ }^{88}$ but appears to fail to signal in pulmonary $\mathrm{T}_{\mathrm{H}} 2$ cells to up-regulate IL-31 release levels in an allergic situation. ${ }^{11}$ Interestingly, asthma was found as one of the dose-dependent side effects in clinical trials with nemolizumab. ${ }^{80}$ The asthmatic events have exclusively been observed in patients with a pre-existing asthma, probably due to improved health and increased activity levels that triggered asthma.

In human bronchial epithelial cells and co-cultures with eosinophils, IL-31 alone or in cooperation with $\mathrm{T}_{\mathrm{H}} 2$ cytokines (IL-4 or IL-13) was shown to alter the production of inflammatory cytokines (IL-6, IL-8), chemokines (CCL2) and growth factors (vascular endothelial growth factor (VEGF), endothelial growth factor (EGF)). CCL2, VEGF and EGF are involved in the recruitment of inflammatory cells, and the autocrine remodelling of epithelial cells ${ }^{89}$ indicating an overall pro-inflammatory role for IL-31 in pulmonary inflammation. Subsequent studies, however, describe IL-31 as a regulatory rather than an inflammatory cytokine in the lung, suggesting a dual role for IL-31 in airway function. Perrigoue et al. described ameliorating effects of the IL-31/IL31RA axis in a murine model of pulmonary type 2 inflammation. ${ }^{90}$ Mice infected withS. mansoni eggs, lodging in the small blood vessels of the lung, develop pulmonary granulomas, due to IL-4/IL-13 signaling, but displayed intensified inflammation of the parenchymal lung tissue when IL31RA was absent. ${ }^{90}$ In this model, IL31RA ${ }^{-/}$mice showed an increased production of type-2 cytokines (IL-4, IL-5, IL-13) upon secondary challenge of isolated lymph node cells withS. mansoni egg antigen. Contrary to initial studies in lung inflammation models, these findings suggest a stronger anti-inflammatory function of IL31RA signaling in the parasite-affected lung tissue. However, the increase in cytokine production in IL31RA $/$ - mice leads to an elevated frequency of alternatively activated macrophages (AAMs) resulting in pulmonary tissue remodeling and fibrosis. Naïve $\mathrm{CD} 4^{+} \mathrm{T}$ cells from IL31RA ${ }^{-/-}$mice demonstrated an augmented proliferative capacity and elevated $\mathrm{T}_{\mathrm{H}} 2$-cytokine production without differentiation into $\mathrm{T}_{\mathrm{H}} 2$ polarized cells. These findings indicate a regulatory engagement of the IL-31/IL31RA axis with GATA-3 in undifferentiated T cells, resulting in a refined control of cytokine production. However, these effects were absent in fully differentiated effector $\mathrm{T}_{\mathrm{H}} 2$ cells. Thus, IL-31 activation of antigen-presenting cells (e.g. macrophages) appears to restrict 
the proliferation of naïve and $\mathrm{T}_{\mathrm{H}} 2$ differentiated cells without impairing their antigen-presenting capacity in lung cells. ${ }^{90}$ Therefore, IL-31 may suppress some innate immune cells, thereby regulating activation of the adaptive immune system during airway inflammation.

IL-31 has recently been implicated in the pathogenesis of nasal polyps (NP) of the sinus mucosa. ${ }^{82}$ Nasal polyps are similar to AD histologically characterized by an infiltration of lymphocytes, especially $\mathrm{T}_{\mathrm{H}} 2$ cells, and eosinophils, considered now as a type- 2 inflammation. The expression of IL-31 is elevated in NPs and IL-31 protein levels correlated with clinical outcome, probably due to the IL-31-amplified $\mathrm{T}_{\mathrm{H}} 2$-skewed inflammation profile. ${ }^{82}$

Expression levels of IL-31 and IL31RA were further found upregulated in the inferior turbinate of patients with allergic rhinitis. ${ }^{91}$ IL31RA primarily localized to submucosal glands and stimulation of A549 cells induced expression of themucin 5AC (MUC5AC) gene suggesting a role for IL-31 in mucus overproduction during nasal allergic inflammation. ${ }^{91}$

In the intestine, IL-31 imbalance seems to be associated with inflammatory bowel disease (IBD). IBD is a frequent autoimmune disorder of the gastrointestinal tract presenting with mucosal inflammation and ulceration due to an imbalance in effector and regulatory $\mathrm{T}$ cells. ${ }^{92,93}$ Two major types of IBD have been described, ulcerative colitis (UC) and Crohn's disease (CD). Expression analysis revealed elevated levels of IL-31, IL31RA and OSMR mRNA in inflamed colonic lesions of CD and UC patients which correlated with lesional IL-8 expression. ${ }^{94}$ Beyond this descriptive finding, an IL-31-specific impact on cellular mechanisms in CD or UC are still missing. In colorectal HCT116 cells, however, pro-inflammatory cytokines (TNF $\alpha$, IL-1 $\beta$ ) and bacterial lipopolysaccharide (LPS) induced IL-31, IL31RA, and OSMR $\beta$ mRNA expression, suggesting involvement of the IL-31 axis in intestinal inflammation. ${ }^{94}$

A pro-inflammatory effect of IL-31 has further been revealed in human colonic subepithelial myofibroblasts. IL-31 dependent activation led toin vitro production of IL-8 (CXCL8), growth-related oncogene$\alpha$ (GRO- $\alpha$ ), CXCL1, monocyte chemoattractant protein-3 (MCP-3), CXCL3 (GRO-3), IL-6 and various metalloproteinases. ${ }^{95}$ The inflammatory impact of IL-31 in vivo on the intestinal epithelial layer has not been shown so far. To elucidate the function of IL-31/IL31RA in chronic intestinal inflammation in humans will necessitate detailed assessments of IL-31-induced signaling traits in disease- promoting cell types, including intestinal epithelial cells, effector/regulatory T cells, nerves and DCs.

Similar to the role of IL-31 signaling in S. mansoni -induced airway inflammation, IL-31-/L31RA has been associated with immunological responses in a murine model of parasitic infection. ${ }^{83}$ Infection of mice with Trichuris muris initiates priming of $\mathrm{T}_{\mathrm{H}} 2$ cells and subsequent production of $\mathrm{T}_{\mathrm{H}} 2$ effector cytokines in the early infection stage and to a conversion of the immune response to a $\mathrm{T}_{\mathrm{H}} 1$-dominated phenotype including IFN $\gamma .{ }^{83}$ Perrigoue et al. demonstrated that IL-31 expression increased under inflammatory conditions when IL-4 was present to skew naïve $\mathrm{T}$ cells towards a $\mathrm{T}_{\mathrm{H}} 2$ phenotype. Like their results on the role of IL31/IL31RA in inflamed lung tissue, the group demonstrated an enhanced production of type-2 cytokines in the absence of IL31RA, implying an immuno-regulatory function of IL-31 in the inflamed intestine. ${ }^{83}$ Nevertheless, although these observations are consistent in lung and intestine, the results await confirmation by additional studies since observations in the skin reveal a rather pro-inflammatory role of IL-31.

\section{Concluding remarks and future perspectives}

Although the biological function of IL-31 has predominantly been associated with AD and pruritus, it is now clear that IL-31 is more than an 'itchy' cytokine. The importance of IL31RA in AD pathophysiology was demonstrated by early and recent trials validating a marked reduction in itch along with improvement of eczema, in some studies, in AD patients using anti-IL31RA antibody. ${ }^{72,74,80}$ The success of these trials in moderate to severe $\mathrm{AD}$ suggests that sole blockage of the IL-31 pathway may be sufficient to achieve an acceptable therapeutic outcome in some patients. However, the success of the IL-4R $\alpha$-inhibiting antibody dupilumab in $\mathrm{AD}$ patients demands further evaluation how to stratify the heterogenous population of $\mathrm{AD}$ patients for the best 'personalized' benefit. More large-scale, long-term studies will help to understand benefit of IL-31-axis inhibition on AD onset, progression and resolution, as well as its impact beside pruritus on 
inflammation (eczema) and barrier dysregulation. A recent trial of nemolizumab in prurigo nodularis patients suggests the applicability of anti-IL31/IL31RA biologicals as therapeutics of certain pruritic diseases ${ }^{96}$ For example, in cancer-associated itch the IL-31 axis might be recognized as a valid treatment target, considering the growth-promoting capacity of IL-31 signaling in various cell types. ${ }^{37,52,97}$ The efficacy of the IL-31-axis inhibition in different types of itch will be important to understand in order to further develop and enhance our therapeutic 'toolbox' for the treatment of currently therapy-refractory pruritic diseases.

Il-31 triggers regulatory responses in epithelial cells of all mucosal sites, namely skin, lung and the GI tract. However, while we begin to understand the cutaneous function of IL-31, its effect on intestinal and pulmonary cell populations is less clear. The involvement of IL-31 in inflammatory disorders of the GI tract or lung is at this stage preliminary and far from being understood. IL-31 likely acts in both tissues in a similar fashion as observed in skin, nurturing inflammatory responses of resident cells and cross-communicating as a regulatory signal to receptive $\mathrm{T}$ cells, DC subsets and probably nerves. However, to fully understand the IL-31-axis in gut, lung and skin during homeostasis and inflammatory conditions, an array of in vitro, ex vivoand in vivo studies will need to be performed.

Deciphering the precise IL-31-induced mechanisms in organ- and disease models, will probably lead to new therapeutic options for the treatment of skin diseases, as well as atopic disorders (nasal polyposis), or disorders in the lung or gastrointestinal tract. However, as mentioned above, because IL-31 itself has a dual inflammatory effect depending on disease stage, the beneficial role of neutralizing the IL-31 pathway needs to be explored for each disease.

\section{Conflict of interest statement}

$\mathrm{AD}, \mathrm{MA}, \mathrm{FA}$ and JB do not declare any conflict of interest. MS is a consultant for Pfizer, Janssen, Eli-Lilly, Novartis, UCB, Celgene, Galderma, Leo, MenloTx. Sanofi, Regeneron. Grants by Pfizer, Novartis, Leo, Galderma. Speaker for Pfizer, Janssen, Eli-Lilly, Novartis, UCB, Celgene, Galderma, Leo, MenloTx, Sanofi, Regeneron.

\section{References}

1. Dillon SR, Sprecher C, Hammond A, et al. Interleukin 31, a cytokine produced by activated T cells, induces dermatitis in mice. Nat Immunol . 2004;5(7):752-760. doi:10.1038/ni1084

2. Scheller J, Chalaris A, Schmidt-Arras D, Rose-John S. The pro- and anti-inflammatory properties of the cytokine interleukin-6.Biochim Biophys Acta . 2011;1813(5):878-888. doi:10.1016/j.bbamcr.2011.01.034

3. Diveu C, Lak-Hal A-HL, Froger J, et al. Predominant expression of the long isoform of GP130like (GPL) receptor is required for interleukin-31 signaling. Eur Cytokine Netw . 15(4):291-302. http://www.ncbi.nlm.nih.gov/pubmed/15627637.

4. Dreuw A, Radtke S, Pflanz S, Lippok BE, Heinrich PC, Hermanns HM. Characterization of the signaling capacities of the novel gp130-like cytokine receptor. J Biol Chem . 2004;279(34):36112-36120. doi:10.1074/jbc.M401122200

5. Sonkoly E, Muller A, Lauerma AI, et al. IL-31: a new link between T cells and pruritus in atopic skin inflammation. J Allergy Clin Immunol . 2006;117(2):411-417. doi:10.1016/j.jaci.2005.10.033

6. Cevikbas F, Wang X, Akiyama T, et al. A sensory neuron-expressed IL-31 receptor mediates T helper cell-dependent itch: Involvement of TRPV1 and TRPA1. J Allergy Clin Immunol . 2014;133(2):448-460. doi:10.1016/j.jaci.2013.10.048

7. Gibbs BF, Patsinakidis N, Raap U. Role of the Pruritic Cytokine IL-31 in Autoimmune Skin Diseases. Front Immunol . 2019;10:1383. doi:10.3389/fimmu.2019.01383

8. Roosterman D, Goerge T, Schneider SW, Bunnett NW, Steinhoff M. Neuronal control of skin function: the skin as a neuroimmunoendocrine organ. Physiol Rev . 2006;86(4):1309-1379. doi:10.1152/physrev.00026.2005 
9. Maier E, Werner D, Duschl A, Bohle B, Horejs-Hoeck J. Human Th2 but not Th9 cells release IL-31 in

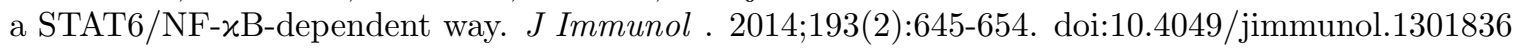

10. Bilsborough J, Leung DYM, Maurer M, et al. IL-31 is associated with cutaneous lymphocyte antigenpositive skin homing T cells in patients with atopic dermatitis. J Allergy Clin Immunol . 2006;117(2):418425. doi:10.1016/j.jaci.2005.10.046

11. Stott B, Lavender P, Lehmann S, Pennino D, Durham S, Schmidt-Weber CB. Human IL-31 is induced by IL-4 and promotes TH2-driven inflammation.J Allergy Clin Immunol . 2013;132(2):446-54.e5. doi:10.1016/j.jaci.2013.03.050

12. Park K, Park J-H, Yang W-J, Lee J-J, Song M-J, Kim H-P. Transcriptional activation of the IL31 gene by NFAT and STAT6. J Leukoc Biol . 2012;91(2):245-257. doi:10.1189/jlb.0111020

13. Hwang JS, Kim G-C, Park E, et al. NFAT1 and JunB cooperatively regulate IL-31 gene expression in CD4+ T cells in health and disease.J Immunol . 2015;194(4):1963-1974. doi:10.4049/jimmunol.1401862

14. Maier E, Mittermeir M, Ess S, et al. Prerequisites for Functional Interleukin 31 Signaling and Its Feedback Regulation by Suppressor of Cytokine Signaling 3 (SOCS3). J Biol Chem . 2015;290(41):2474724759. doi:10.1074/jbc.M115.661306

15. Paus R, Schmelz M, Bíró T, Steinhoff M. Frontiers in pruritus research: scratching the brain for more effective itch therapy. J Clin Invest . 2006;116(5):1174-1186. doi:10.1172/JCI28553

16. Cevikbas F, Lerner EA. Physiology and Pathophysiology of Itch.Physiol Rev . 2020;100(3):945-982. doi:10.1152/physrev.00017.2019

17. Steinhoff M, Schmelz M, Szabó IL, Oaklander AL. Clinical presentation, management, and pathophysiology of neuropathic itch.Lancet Neurol . 2018;17(8):709-720. doi:10.1016/S1474-4422(18)30217-5

18. Steinhoff M, Bienenstock J, Schmelz M, Maurer M, Wei E, Bíró T. Neurophysiological, neuroimmunological, and neuroendocrine basis of pruritus. J Invest Dermatol . 2006;126(8):1705-1718. doi:10.1038/sj.jid.5700231

19. Steinhoff M, Cevikbas F, Yeh I, Chong K, Buddenkotte J, Ikoma A. Evaluation and management of a patient with chronic pruritus. J Allergy Clin Immunol . 2012;130(4):1015-6.e7. doi:10.1016/j.jaci.2012.08.006

20. Yosipovitch G, Bernhard JD. Clinical practice. Chronic pruritus. N Engl J Med . 2013;368(17):1625-1634. doi:10.1056/NEJMcp1208814

21. Steinhoff MS, von Mentzer B, Geppetti P, Pothoulakis C, Bunnett NW. Tachykinins and their receptors: contributions to physiological control and the mechanisms of disease. Physiol Rev . 2014;94(1):265-301. doi:10.1152/physrev.00031.2013

22. Ständer S, Steinhoff M, Schmelz M, Weisshaar E, Metze D, Luger T. Neurophysiology of pruritus: cutaneous elicitation of itch. Arch Dermatol . 2003;139(11):1463-1470. doi:10.1001/archderm.139.11.1463

23. Meng J, Moriyama M, Feld M, et al. New mechanism underlying IL-31-induced atopic dermatitis. $J$ Allergy Clin Immunol . 2018;141(5):1677-1689.e8. doi:10.1016/j.jaci.2017.12.1002

24. Meng J, Wang J, Buddenkotte J, Buhl T, Steinhoff M. Role of SNAREs in Atopic DermatitisRelated Cytokine Secretion and Skin-Nerve Communication. J Invest Dermatol . 2019;139(11):2324-2333. doi:10.1016/j.jid.2019.04.017

25. Bautista DM, Wilson SR, Hoon MA. Why we scratch an itch: the molecules, cells and circuits of itch. Nat Neurosci . 2014;17(2):175-182. doi:10.1038/nn.3619

26. Hoon MA. Molecular dissection of itch. Curr Opin Neurobiol . 2015;34:61-66. doi:10.1016/j.conb.2015.01.017 
27. Usoskin D, Furlan A, Islam S, et al. Unbiased classification of sensory neuron types by large-scale singlecell RNA sequencing. Nat Neurosci . 2015;18(1):145-153. doi:10.1038/nn.3881

28. Oh M-H, Oh SY, Lu J, et al. TRPA1-dependent pruritus in IL-13-induced chronic atopic dermatitis. $J$ Immunol . 2013;191(11):5371-5382. doi:10.4049/jimmunol.1300300

29. Imamachi N, Park GH, Lee H, et al. TRPV1-expressing primary afferents generate behavioral responses to pruritogens via multiple mechanisms. Proc Natl Acad Sci U S A . 2009;106(27):11330-11335. doi:10.1073/pnas.0905605106

30. Kido-Nakahara M, Buddenkotte J, Kempkes C, et al. Neural peptidase endothelin-converting enzyme 1 regulates endothelin 1-induced pruritus.J Clin Invest . 2014;124(6):2683-2695. doi:10.1172/JCI67323

31. Wilson SR, Thé L, Batia LM, et al. The epithelial cell-derived atopic dermatitis cytokine TSLP activates neurons to induce itch. Cell . 2013;155(2):285-295. doi:10.1016/j.cell.2013.08.057

32. Oetjen LK, Mack MR, Feng J, et al. Sensory Neurons Co-opt Classical Immune Signaling Pathways to Mediate Chronic Itch. Cell . 2017;171(1):217-228.e13. doi:10.1016/j.cell.2017.08.006

33. Campion M, Smith L, Gatault S, Métais C, Buddenkotte J, Steinhoff M. Interleukin-4 and interleukin-13 evoke scratching behaviour in mice.Exp Dermatol . 2019;28(12):1501-1504. doi:10.1111/exd.14034

34. Werfel T, Allam J-P, Biedermann T, et al. Cellular and molecular immunologic mechanisms in patients with atopic dermatitis. J Allergy Clin Immunol . 2016;138(2):336-349. doi:10.1016/j.jaci.2016.06.010

35. Cevikbas F, Braz JM, Wang X, et al. Synergistic antipruritic effects of gamma aminobutyric acid A and B agonists in a mouse model of atopic dermatitis. J Allergy Clin Immunol . 2017;140(2):454-464.e2. doi:10.1016/j.jaci.2017.02.001

36. Kato A, Fujii E, Watanabe T, et al. Distribution of IL-31 and its receptor expressing cells in skin of atopic dermatitis. J Dermatol Sci . 2014;74(3):229-235. doi:10.1016/j.jdermsci.2014.02.009

37. Feld M, Garcia R, Buddenkotte J, et al. The pruritus- and TH2-associated cytokine IL-31 promotes growth of sensory nerves. J Allergy Clin Immunol . 2016;138(2):500-508.e24. doi:10.1016/j.jaci.2016.02.020

38. Tobin D, Nabarro G, Baart de la Faille H, van Vloten WA, van der Putte SC, Schuurman HJ. Increased number of immunoreactive nerve fibers in atopic dermatitis. J Allergy Clin Immunol . 1992;90(4 Pt 1):613622. doi:10.1016/0091-6749(92)90134-n

39. Cevikbas F, Steinhoff A, Homey B, Steinhoff M. Neuroimmune interactions in allergic skin diseases. Curr Opin Allergy Clin Immunol . 2007;7(5):365-373. doi:10.1097/ACI.0b013e3282a644d2

40. Lerner EA. Is the Nervous System More Important Than the Immune System in Itch and Atopic Dermatitis? J Investig dermatology Symp Proc . 2018;19(2):S94. doi:10.1016/j.jisp.2018.10.002

41. Tominaga M, Takamori K. Itch and nerve fibers with special reference to atopic dermatitis: therapeutic implications. J Dermatol . 2014;41(3):205-212. doi:10.1111/1346-8138.12317

42. Emtestam L, Hagströmer L, Dou Y-C, Sartorius K, Johansson O. PGP 9.5 distribution patterns in biopsies from early lesions of atopic dermatitis. Arch Dermatol Res . 2012;304(10):781-785. doi:10.1007/s00403012-1246-0

43. Hosokawa T, Kusugami K, Ina K, et al. Interleukin-6 and soluble interleukin-6 receptor in the colonic mucosa of inflammatory bowel disease. J Gastroenterol Hepatol . 1999;14(10):987-996. doi:10.1046/j.14401746.1999.01989.x

44. Xing Z, Gauldie J, Cox G, et al. IL-6 is an antiinflammatory cytokine required for controlling local or systemic acute inflammatory responses. J Clin Invest . 1998;101(2):311-320. doi:10.1172/JCI1368 
45. Robinson ES, Werth VP. The role of cytokines in the pathogenesis of cutaneous lupus erythematosus. Cytokine . 2015;73(2):326-334. doi:10.1016/j.cyto.2015.01.031

46. West NR, Hegazy AN, Owens BMJ, et al. Oncostatin M drives intestinal inflammation and predicts response to tumor necrosis factor-neutralizing therapy in patients with inflammatory bowel disease. Nat Med . 2017;23(5):579-589. doi:10.1038/nm.4307

47. Jones SA, Jenkins BJ. Recent insights into targeting the IL-6 cytokine family in inflammatory diseases and cancer. Nat Rev Immunol . 2018;18(12):773-789. doi:10.1038/s41577-018-0066-7

48. Imai Y. Interleukin-33 in atopic dermatitis. $J$ Dermatol Sci . 2019;96(1):2-7. doi:10.1016/j.jdermsci.2019.08.006

49. Lee J-H, Wang L-C, Yu H-H, Lin Y-T, Yang Y-H, Chiang B-L. Type I IL-1 receptor (IL1RI) as potential new therapeutic target for bronchial asthma. Mediators Inflamm . 2010;2010:567351. doi:10.1155/2010/567351

50. Hawro T, Saluja R, Weller K, Altrichter S, Metz M, Maurer M. Interleukin-31 does not induce immediate itch in atopic dermatitis patients and healthy controls after skin challenge. Allergy . 2014;69(1):113-117. doi:10.1111/all.12316

51. Vocca L, Di Sano C, Uasuf CG, et al. IL-33/ST2 axis controls Th2/IL-31 and Th17 immune response in allergic airway diseases.Immunobiology . 2015;220(8):954-963. doi:10.1016/j.imbio.2015.02.005

52. Singh B, Jegga AG, Shanmukhappa KS, et al. IL-31-Driven Skin Remodeling Involves Epidermal Cell Proliferation and Thickening That Lead to Impaired Skin-Barrier Function. PLoS One . 2016;11(8):e0161877. doi:10.1371/journal.pone.0161877

53. Cornelissen C, Marquardt Y, Czaja K, et al. IL-31 regulates differentiation and filaggrin expression in human organotypic skin models. J Allergy Clin Immunol . 2012;129(2):426-433, 433.e1-8. doi:10.1016/j.jaci.2011.10.042

54. Hänel KH, Pfaff CM, Cornelissen C, et al. Control of the Physical and Antimicrobial Skin Barrier by an IL-31-IL-1 Signaling Network.J Immunol . 2016;196(8):3233-3244. doi:10.4049/jimmunol.1402943

55. Santamaria LF, Perez Soler MT, Hauser C, Blaser K. Allergen specificity and endothelial transmigration of $\mathrm{T}$ cells in allergic contact dermatitis and atopic dermatitis are associated with the cutaneous lymphocyte antigen. Int Arch Allergy Immunol . 107(1-3):359-362. doi:10.1159/000237032

56. Kasraie S, Niebuhr M, Baumert K, Werfel T. Functional effects of interleukin 31 in human primary keratinocytes. Allergy . 2011;66(7):845-852. doi:10.1111/j.1398-9995.2011.02545.x

57. Santamaria Babi LF, Picker LJ, Perez Soler MT, et al. Circulating allergen-reactive T cells from patients with atopic dermatitis and allergic contact dermatitis express the skin-selective homing receptor, the cutaneous lymphocyte-associated antigen. J Exp Med . 1995;181(5):1935-1940. doi:10.1084/jem.181.5.1935

58. Akdis M, Akdis CA, Weigl L, Disch R, Blaser K. Skin-homing, CLA+ memory T cells are activated in atopic dermatitis and regulate IgE by an IL-13-dominated cytokine pattern: IgG4 counter-regulation by CLA- memory T cells. J Immunol . 1997;159(9):4611-4619. http://www.ncbi.nlm.nih.gov/pubmed/9379063.

59. Khattri S, Shemer A, Rozenblit M, et al. Cyclosporine in patients with atopic dermatitis modulates activated inflammatory pathways and reverses epidermal pathology. J Allergy Clin Immunol . 2014;133(6):16261634. doi:10.1016/j.jaci.2014.03.003

60. Lin Y-T, Wang C-T, Chiang B-L. Role of bacterial pathogens in atopic dermatitis. Clin Rev Allergy Immunol . 2007;33(3):167-177. doi:10.1007/s12016-007-0044-5

61. Torres MJ, Gonzalez FJ, Corzo JL, et al. Circulating CLA+ lymphocytes from children with atopic dermatitis contain an increased percentage of cells bearing staphylococcal-related T-cell receptor variable 
segments. Clin Exp Allergy . 1998;28(10):1264-1272. doi:10.1046/j.1365-2222.1998.00397.x

62. Szegedi K, van Lier A, Res PC, et al. House dust mite allergens Der f and Der p induce IL-31 production by blood-derived T cells from atopic dermatitis patients. Exp Dermatol . 2018;27(4):393-395. doi:10.1111/exd.13438

63. Horejs-Hoeck J, Schwarz H, Lamprecht S, et al. Dendritic cells activated by IFN-r/STAT1 express IL-31 receptor and release proinflammatory mediators upon IL-31 treatment. J Immunol . 2012;188(11):5319-5326. doi:10.4049/jimmunol.1101044

64. Wong C-K, Leung KM-L, Qiu H-N, Chow JY-S, Choi AOK, Lam CW-K. Activation of eosinophils interacting with dermal fibroblasts by pruritogenic cytokine IL-31 and alarmin IL-33: implications in atopic dermatitis. PLoS One . 2012;7(1):e29815. doi:10.1371/journal.pone.0029815

65. Cheung PF-Y, Wong C-K, Ho AW-Y, Hu S, Chen D-P, Lam CW-K. Activation of human eosinophils and epidermal keratinocytes by Th2 cytokine IL-31: implication for the immunopathogenesis of atopic dermatitis. Int Immunol . 2010;22(6):453-467. doi:10.1093/intimm/dxq027

66. Moyle M, Cevikbas F, Harden JL, Guttman-Yassky E. Understanding the immune landscape in atopic dermatitis: The era of biologics and emerging therapeutic approaches. Exp Dermatol . 2019;28(7):756-768. doi:10.1111/exd.13911

67. Beck LA, Thaçi D, Hamilton JD, et al. Dupilumab treatment in adults with moderate-to-severe atopic dermatitis. N Engl J Med . 2014;371(2):130-139. doi:10.1056/NEJMoa1314768

68. Grimstad O, Sawanobori Y, Vestergaard C, et al. Anti-interleukin-31-antibodies ameliorate scratching behaviour in NC/Nga mice: a model of atopic dermatitis. Exp Dermatol . 2009;18(1):35-43. doi:10.1111/j.16000625.2008.00766.x

69. Arai I, Tsuji M, Miyagawa K, Takeda H, Akiyama N, Saito S. Repeated administration of IL-31 upregulates IL-31 receptor A (IL-31RA) in dorsal root ganglia and causes severe itch-associated scratching behaviour in mice. Exp Dermatol . 2015;24(1):75-78. doi:10.1111/exd.12587

70. Kasutani K, Fujii E, Ohyama S, et al. Anti-IL-31 receptor antibody is shown to be a potential therapeutic option for treating itch and dermatitis in mice. Br J Pharmacol . 2014;171(22):5049-5058. doi:10.1111/bph.12823

71. Kabashima K, Furue M, Hanifin JM, et al. Nemolizumab in patients with moderate-to-severe atopic dermatitis: Randomized, phase II, long-term extension study. J Allergy Clin Immunol . 2018;142(4):11211130.e7. doi:10.1016/j.jaci.2018.03.018

72. Nemoto O, Furue M, Nakagawa H, et al. The first trial of CIM331, a humanized antihuman interleukin-31 receptor $\mathrm{A}$ antibody, in healthy volunteers and patients with atopic dermatitis to evaluate safety, tolerability and pharmacokinetics of a single dose in a randomized, double-blind, placebo-co. $\mathrm{Br} J$ Dermatol . 2016;174(2):296-304. doi:10.1111/bjd.14207

73. Ruzicka T, Hanifin JM, Furue M, et al. Anti-Interleukin-31 Receptor A Antibody for Atopic Dermatitis. $N$ Engl J Med . 2017;376(9):826-835. doi:10.1056/NEJMoa1606490

74. Kabashima K, Matsumura T, Komazaki H, Kawashima M, Nemolizumab-JP01 Study Group. Trial of Nemolizumab and Topical Agents for Atopic Dermatitis with Pruritus. N Engl J Med . 2020;383(2):141-150. doi:10.1056/NEJMoa1917006

75. Oyama S, Kitamura H, Kuramochi T, et al. Cynomolgus monkey model of interleukin-31-induced scratching depicts blockade of human interleukin-31 receptor A by a humanized monoclonal antibody. Exp Dermatol . 2018;27(1):14-21. doi:10.1111/exd.13236

76. Gonzales AJ, Humphrey WR, Messamore JE, et al. Interleukin-31: its role in canine pruritus and 
naturally occurring canine atopic dermatitis. Vet Dermatol . 2013;24(1):48-53.e11-2. doi:10.1111/j.13653164.2012.01098.x

77. Michels GM, Ramsey DS, Walsh KF, et al. A blinded, randomized, placebo-controlled, dose determination trial of lokivetmab (ZTS-00103289), a caninized, anti-canine IL-31 monoclonal antibody in client owned dogs with atopic dermatitis. Vet Dermatol . 2016;27(6):478-e129. doi:10.1111/vde.12376

78. Michels GM, Walsh KF, Kryda KA, et al. A blinded, randomized, placebo-controlled trial of the safety of lokivetmab (ZTS-00103289), a caninized anti-canine IL-31 monoclonal antibody in client-owned dogs with atopic dermatitis. Vet Dermatol . 2016;27(6):505-e136. doi:10.1111/vde.12364

79. Lewis KE, Holdren MS, Maurer MF, et al. Interleukin (IL) 31 induces in cynomolgus monkeys a rapid and intense itch response that can be inhibited by an IL-31 neutralizing antibody. J Eur Acad Dermatol Venereol . 2017;31(1):142-150. doi:10.1111/jdv.13794

80. Silverberg JI, Pinter A, Pulka G, et al. Phase 2B randomized study of nemolizumab in adults with moderate-to-severe atopic dermatitis and severe pruritus. J Allergy Clin Immunol . 2020;145(1):173-182. doi:10.1016/j.jaci.2019.08.013

81. Chattopadhyay S, Tracy E, Liang P, Robledo O, Rose-John S, Baumann H. Interleukin-31 and oncostatin$\mathrm{M}$ mediate distinct signaling reactions and response patterns in lung epithelial cells. $J$ Biol Chem . 2007;282(5):3014-3026. doi:10.1074/jbc.M609655200

82. Ouyang H, Cheng J, Zheng Y, Du J. Role of IL-31 in regulation of Th2 cytokine levels in patients with nasal polyps. Eur Arch Otorhinolaryngol . 2014;271(10):2703-2709. doi:10.1007/s00405-014-2913-x

83. Perrigoue JG, Zaph C, Guild K, Du Y, Artis D. IL-31-IL-31R interactions limit the magnitude of Th2 cytokine-dependent immunity and inflammation following intestinal helminth infection. J Immunol . 2009;182(10):6088-6094. doi:10.4049/jimmunol.0802459

84. Fukada T, Hibi M, Yamanaka Y, et al. Two signals are necessary for cell proliferation induced by a cytokine receptor gp130: involvement of STAT3 in anti-apoptosis. Immunity . 1996;5(5):449-460. doi:10.1016/s10747613(00)80501-4

85. Fukada T, Ohtani T, Yoshida Y, et al. STAT3 orchestrates contradictory signals in cytokine-induced G1 to S cell-cycle transition. EMBO J . 1998;17(22):6670-6677. doi:10.1093/emboj/17.22.6670

86. Lei Z, Liu G, Huang Q, et al. SCF and IL-31 rather than IL-17 and BAFF are potential indicators in patients with allergic asthma.Allergy . 2008;63(3):327-332. doi:10.1111/j.1398-9995.2007.01566.x

87. Guarneri F, Minciullo PL, Mannucci C, et al. IL-31 and IL-33 circulating levels in allergic contact dermatitis. Eur Ann Allergy Clin Immunol . 2015;47(5):156-158. http://www.ncbi.nlm.nih.gov/pubmed/26357000.

88. Endo Y, Hirahara K, Iinuma T, et al. The interleukin-33-p38 kinase axis confers memory T helper 2 cell pathogenicity in the airway.Immunity . 2015;42(2):294-308. doi:10.1016/j.immuni.2015.01.016

89. Ip WK, Wong CK, Li MLY, Li PW, Cheung PFY, Lam CWK. Interleukin-31 induces cytokine and chemokine production from human bronchial epithelial cells through activation of mitogen-activated protein kinase signalling pathways: implications for the allergic response.Immunology . 2007;122(4):532-541. doi:10.1111/j.1365-2567.2007.02668.x

90. Perrigoue JG, Li J, Zaph C, et al. IL-31-IL-31R interactions negatively regulate type 2 inflammation in the lung. J Exp Med . 2007;204(3):481-487. doi:10.1084/jem.20061791

91. Shah SA, Ishinaga H, Hou B, Okano M, Takeuchi K. Effects of interleukin-31 on MUC5AC gene expression in nasal allergic inflammation.Pharmacology . 2013;91(3-4):158-164. doi:10.1159/000346609

92. Baumgart DC, Sandborn WJ. Inflammatory bowel disease: clinical aspects and established and evolving therapies. Lancet (London, England) . 2007;369(9573):1641-1657. doi:10.1016/S0140-6736(07)60751-X 
93. Koenecke C, Förster R. CCR9 and inflammatory bowel disease.Expert Opin Ther Targets . 2009;13(3):297306. doi:10.1517/14728220902762928

94. Dambacher J, Beigel F, Seiderer J, et al. Interleukin 31 mediates MAP kinase and STAT1/3 activation in intestinal epithelial cells and its expression is upregulated in inflammatory bowel disease. Gut . 2007;56(9):1257-1265. doi:10.1136/gut.2006.118679

95. Yagi Y, Andoh A, Nishida A, et al. Interleukin-31 stimulates production of inflammatory mediators from human colonic subepithelial myofibroblasts. Int $J$ Mol Med . 2007;19(6):941-946. http://www.ncbi.nlm.nih.gov/pubmed/17487427.

96. Ständer S, Yosipovitch G, Legat FJ, et al. Trial of Nemolizumab in Moderate-to-Severe Prurigo Nodularis. N Engl J Med . 2020;382(8):706-716. doi:10.1056/NEJMoa1908316

97. Broxmeyer HE, Li J, Hangoc G, et al. Regulation of myeloid progenitor cell proliferation/survival by IL-31 receptor and IL-31.Exp Hematol . 2007;35(4 Suppl 1):78-86. doi:10.1016/j.exphem.2007.01.028

Table 1: Clinical trial design for completed trials testing nemolizumab efficacy in AD and PN

\begin{tabular}{|c|c|c|c|c|c|}
\hline & $\begin{array}{l}\text { Nemolizumab } \\
\text { (CD14152; } \\
\text { CIM331; } \\
\text { humanized } \\
\text { IgG2x? }\end{array}$ & $\begin{array}{l}\text { Nemolizumab } \\
\text { (CD14152; } \\
\text { CIM331; } \\
\text { humanized } \\
\text { IgG2x? }\end{array}$ & $\begin{array}{l}\text { Nemolizumab } \\
\text { (CD14152; } \\
\text { CIM331; } \\
\text { humanized } \\
\text { IgG2x? }\end{array}$ & $\begin{array}{l}\text { Nemolizumab } \\
\text { (CD14152; } \\
\text { CIM331; } \\
\text { humanized } \\
\text { IgG2x? }\end{array}$ & $\begin{array}{l}\text { Nemolizumab } \\
\text { (CD14152; } \\
\text { CIM331; } \\
\text { humanized } \\
\text { IgG2x? }\end{array}$ \\
\hline $\begin{array}{l}\text { Mechanism } \\
\text { of biologic }\end{array}$ & $\begin{array}{l}\text { Anti-IL31RA } \\
\text { monoclonal } \\
\text { antibody } \\
\text { blocking IL- } \\
\text { 31-dependent } \\
\text { receptor } \\
\text { activation and } \\
\text { downstream } \\
\text { signaling }\end{array}$ & $\begin{array}{l}\text { Anti-IL31RA } \\
\text { monoclonal } \\
\text { antibody } \\
\text { blocking IL- } \\
\text { 31-dependent } \\
\text { receptor } \\
\text { activation and } \\
\text { downstream } \\
\text { signaling }\end{array}$ & $\begin{array}{l}\text { Anti-IL31RA } \\
\text { monoclonal } \\
\text { antibody } \\
\text { blocking IL- } \\
\text { 31-dependent } \\
\text { receptor } \\
\text { activation and } \\
\text { downstream } \\
\text { signaling }\end{array}$ & $\begin{array}{l}\text { Anti-IL31RA } \\
\text { monoclonal } \\
\text { antibody } \\
\text { blocking IL- } \\
\text { 31-dependent } \\
\text { receptor } \\
\text { activation and } \\
\text { downstream } \\
\text { signaling }\end{array}$ & $\begin{array}{l}\text { Anti-IL31RA } \\
\text { monoclonal } \\
\text { antibody } \\
\text { blocking IL- } \\
\text { 31-dependent } \\
\text { receptor } \\
\text { activation and } \\
\text { downstream } \\
\text { signaling }\end{array}$ \\
\hline Study design & $\begin{array}{l}\text { Randomized, } \\
\text { placebo- } \\
\text { controlled, } \\
\text { double-blind, } \\
\text { multi-center }\end{array}$ & $\begin{array}{l}\text { Randomized, } \\
\text { placebo- } \\
\text { controlled, } \\
\text { double-blind, } \\
\text { multi-center }\end{array}$ & $\begin{array}{l}\text { Randomized, } \\
\text { placebo- } \\
\text { controlled, } \\
\text { double-blind, } \\
\text { multi-center } \\
\text { dose ranging }\end{array}$ & $\begin{array}{l}\text { Randomized, } \\
\text { placebo- } \\
\text { controlled, } \\
\text { double-blind, } \\
\text { multi-center } \\
\text { XCIMA study } \\
\text { group }\end{array}$ & $\begin{array}{l}\text { Randomized, } \\
\text { placebo- } \\
\text { controlled, } \\
\text { double-blind, } \\
\text { multi-center }\end{array}$ \\
\hline $\begin{array}{l}\text { Identifier } \\
\text { number }\end{array}$ & $\begin{array}{l}\text { JapicCTI- } \\
173740\end{array}$ & NCT03181503 & NCT03100344 & NCT01986933 & NA \\
\hline Publication & $\begin{array}{l}\text { Kabashima et } \\
\text { al., } 2020,{ }^{74}\end{array}$ & $\begin{array}{l}\text { Stander et al., } \\
2020,{ }^{96}\end{array}$ & $\begin{array}{l}\text { Siverberg et al, } \\
2020,{ }^{80}\end{array}$ & $\begin{array}{l}\text { Part A: Ruzicka } \\
\text { et al 2017, } \\
\text { Part B: } \\
\text { Kabashima et } \\
\text { al., } 2018,{ }^{71}\end{array}$ & $\begin{array}{l}\text { Nemoto et al } \\
2016,{ }^{72}\end{array}$ \\
\hline Phase & 3 & 2 & $2 \mathrm{~B}$ & 2 & $1 / 1 b$ \\
\hline $\begin{array}{l}\text { Recruitment } \\
\text { status }\end{array}$ & Completed & Completed & Completed & Completed & Completed \\
\hline Duration & $16 \mathrm{wk}$ & $16 \mathrm{wk}$ & $32 \mathrm{wk}$ & $\begin{array}{l}\text { Part A: } 12 \mathrm{wk} \\
\text { Part B: } 52 \mathrm{wk}\end{array}$ & 127 days \\
\hline $\begin{array}{l}\text { Participant } \\
\text { ethnicity }\end{array}$ & Japanese & NA & NA & NA & $\begin{array}{l}\text { Japanese, } \\
\text { white }\end{array}$ \\
\hline
\end{tabular}




\begin{tabular}{|c|c|c|c|c|c|}
\hline & $\begin{array}{l}\text { Nemolizumab } \\
\text { (CD14152; } \\
\text { CIM331; } \\
\text { humanized } \\
\text { IgG2x? }\end{array}$ & $\begin{array}{l}\text { Nemolizumab } \\
\text { (CD14152; } \\
\text { CIM331; } \\
\text { humanized } \\
\text { IgG2x? }\end{array}$ & $\begin{array}{l}\text { Nemolizumab } \\
\text { (CD14152; } \\
\text { CIM331; } \\
\text { humanized } \\
\text { IgG2x? }\end{array}$ & $\begin{array}{l}\text { Nemolizumab } \\
\text { (CD14152; } \\
\text { CIM331; } \\
\text { humanized } \\
\text { IgG2x? }\end{array}$ & $\begin{array}{l}\text { Nemolizumab } \\
\text { (CD14152; } \\
\text { CIM331; } \\
\text { humanized } \\
\text { IgG2x? }\end{array}$ \\
\hline Dosing & $\begin{array}{l}60 \mathrm{mg} \text { Q4W, } \\
\text { subcutaneous }\end{array}$ & $\begin{array}{l}0.5 \mathrm{mg} / \mathrm{kg} \mathrm{Q} 4 \mathrm{~W} \\
\text { up to wk } 8, \\
\text { subcutaneous }\end{array}$ & $\begin{array}{l}10,30,90 \mathrm{mg} \\
\text { Q4W up to wk } \\
20, \text { subcutaneous }\end{array}$ & $\begin{array}{l}\text { Pt A: } 0.1,0.5, \text { or } \\
2.0 \mathrm{mg} / \mathrm{kg} \mathrm{Q} 4 \mathrm{~W} \text {, } \\
\text { or } 2.0 \mathrm{mg} / \mathrm{kg} \\
\text { Q } 8 W, \text { wk } 12 \mathrm{Pt} \\
\text { B: above, wk } 52\end{array}$ & $\begin{array}{l}0.003,0.01,0.03, \\
0.1,0.3,1.0,3.0 \\
\mathrm{mg} / \mathrm{kg}, \text { single } \\
\text { dose, } \\
\text { subcutaneous }\end{array}$ \\
\hline Sample size & $\begin{array}{l}\mathrm{N}=143(72 \\
\mathrm{PbO}),(204 \\
\text { target size })\end{array}$ & $\mathrm{N}=70(34 \mathrm{PbO})$ & $\begin{array}{l}\mathrm{N}=226(57 \\
\mathrm{PbO})\end{array}$ & $\begin{array}{l}\text { Pt A: } \mathrm{n}=216 \\
(264 \text { target size); } \\
\text { Pt B: } \mathrm{n}=131 \\
(191 \text { target size })\end{array}$ & $\begin{array}{l}\mathrm{N}=145 \text { Pt A: } \mathrm{n} \\
=56(14 \mathrm{PbO}) ; \\
\mathrm{Pt} \mathrm{B}: \mathrm{n}=24(6 \\
\mathrm{PbO}) ; \mathrm{Pt} \mathrm{C}: \mathrm{n}= \\
36(9 \mathrm{PbO})\end{array}$ \\
\hline $\begin{array}{l}\text { Key inclu- } \\
\text { sion/exclusion } \\
\text { criteria }\end{array}$ & $\begin{array}{l}\text { AD with } \\
\text { moderate or } \\
\text { severe pruritus }\end{array}$ & $\begin{array}{l}\text { Clinical } \\
\text { diagnosis of } \\
\text { PN [?] } 6 \\
\text { months, } \\
\text { pruritus }\end{array}$ & $\begin{array}{l}\text { Chronic AD } \\
\text { [?] } 2 \text { years }\end{array}$ & Pruritic AD & $\begin{array}{l}\text { AD of } \\
\text { moderate or } \\
\text { greater } \\
\text { severity }\end{array}$ \\
\hline $\begin{array}{l}\text { Primary } \\
\text { endpoint }\end{array}$ & $\begin{array}{l}\text { Mean } \% \Delta \\
\text { VAS (range } \\
0-100 \text { ), wk } 16\end{array}$ & $\begin{array}{l}\% \Delta \text { pruritus } \\
\text { NRS score } \\
\text { using LOCF, } \\
\text { MI and } \\
\text { observed data, } \\
\text { wk } 4 \text {; }\end{array}$ & $\begin{array}{l}\% \Delta \text { EASI, wk } \\
24\end{array}$ & $\begin{array}{l}\% \Delta \text { VAS, wk } \\
12\end{array}$ & $\begin{array}{l}\text { Assessment of } \\
\mathrm{AE}\end{array}$ \\
\hline
\end{tabular}

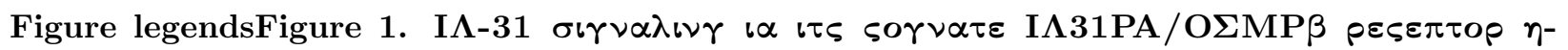
$\varepsilon \tau \varepsilon \rho о \delta ı \mu \varepsilon \rho$. Binding of IL-31 leads to receptor dimerization, cytosolic phosphorylation and subsequent activation of canonical kinase pathways including JAK/STAT, PI3K/AKT and MAPK cascades. Note that OSMR $\beta$ specific recruitment of the adapter proteins SHC and SHP-2 facilitates phosphorylation and activation of various MAPK cascade members. Dependent on cell type and cell environment, downstream transcription factor activation subsequently controls the expression of genes involved in inflammation, proliferation and cell survival.Figure 2. Illustration depicting the effects of IL-31 in atopic dermatitis skin. $\mathrm{CLA}^{+} \mathrm{T}_{\mathrm{H}} 2$ cells are abundant allergen-reactive $\mathrm{T}$ cells in the circulation of $\mathrm{AD}$ patients and are recruited to the $\mathrm{AD}$-affected skin through CCL17 and CCL22 signaling. In the skin, CLA ${ }^{+} \mathrm{T}_{\mathrm{H}} 2$ cells secrete IL-31, which in turn can activate IL31RA/OSMRß-expressing cutaneous sensory nerves, innate immune cells including DCs, monocytes and eosinophils (not shown) and keratinocytes of the epidermis. In human AD skin, keratinocytes show elevated levels of IL31RA/OSMR $\beta$ expression resulting in stronger receptiveness to IL-31. Cutaneous IL-31 signaling results in peripheral pruritus, (neuro)-inflammation and an impaired barrier function through IL-31-mediated suppression of terminally differentiated genes such as filaggrin and a reduced lipid envelope. Activated keratinocytes secrete various chemo-attractants that trigger an additional recruitment of IL-31-expressing $\mathrm{CLA}^{+} \mathrm{T}_{\mathrm{H}} 2$ cells to the site of inflammation, nurturing a feedback-in loop of skin inflammation and pruritus. Human and mouse sensory neurons express IL31RA/OSMR $\beta$ mostly in neurons that also co-express TRPV1. Sensory nerve endings demonstrate high IL31RA levels in AD skin and IL-31 stimulation leads to enhanced neuronal growth probably causing pruritic hypersensitivity and an elevation of peripheral pruritus. In the central nervous system, IL31RA/OSMR $\beta$ immunoreactivity has been shown in the dorsal horn of the spinal cord, indicating that IL-31 signaling is likely involved in central pruritus and sensitization of spinal cord neurons.Figure 3. IL-31 Function in Mucosal Sites. 

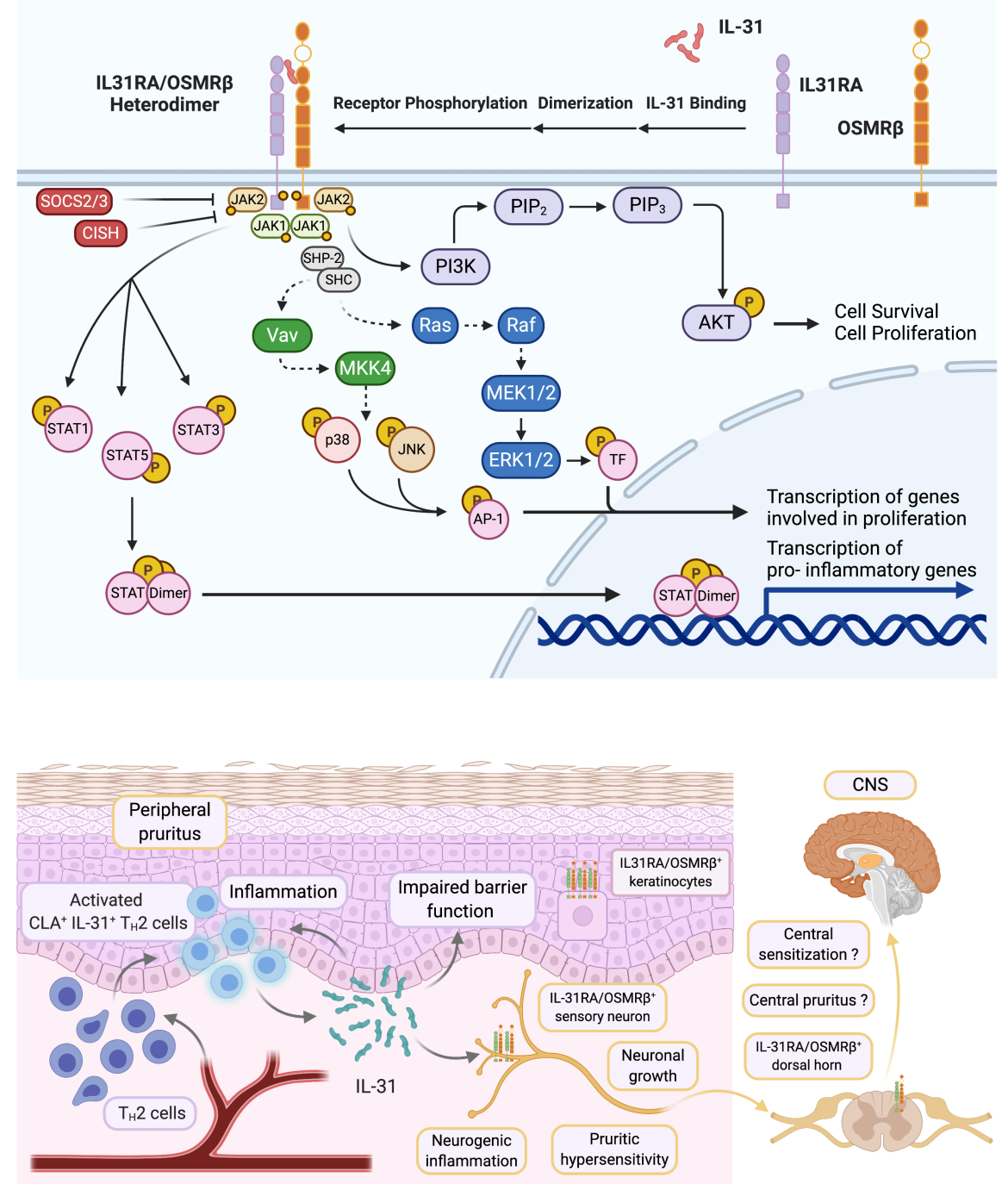

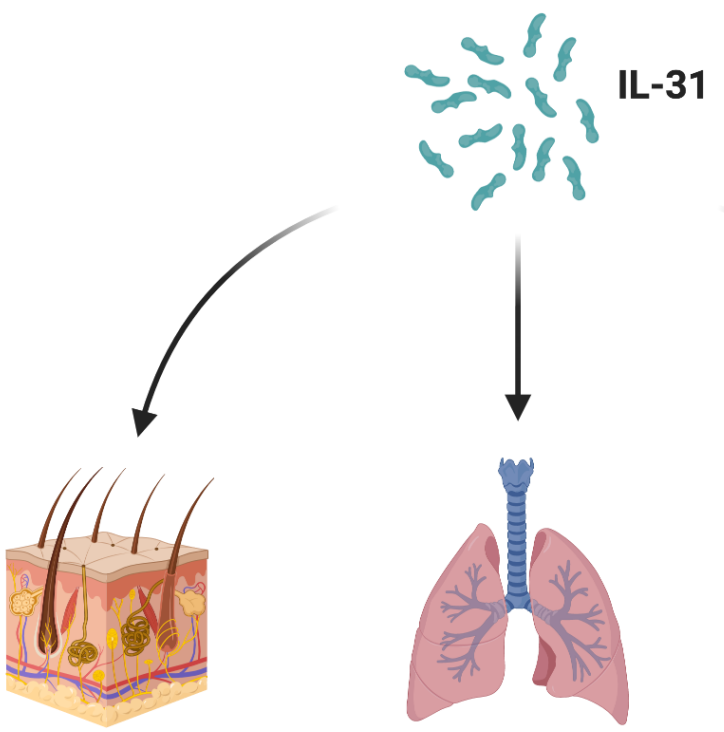

Pruritus

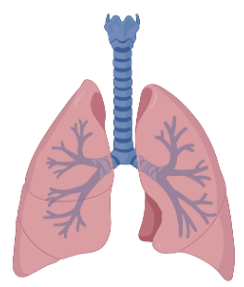

Inflammation

Lung homeostasis

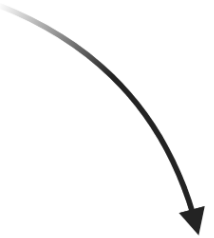

Barrier function

Differentiation

Biased in inflammation:

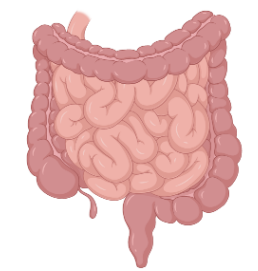

Mechanical integrity

Anti- $\leftrightarrow$ pro-inflammatory

Inflammation

Immune regulation

Allergy

Innate immunity

Adaptive immunity 